Mahinkanda, M.M.M.P., Sandanayake, Y.G. and Ekanayake, B.J., 2019. Bridging the theory-practice gap in value management in Sri Lankan construction industry. In: Sandanayake, Y.G., Gunatilake, S. and Waidyasekara, A. (eds). Proceedings of the $8^{\text {th }}$ World Construction Symposium, Colombo, Sri Lanka, 8-10 November 2019, pp. 147-157. DOI: doi.org/10.31705/WCS.2019.15. Available at: https://2019.ciobwcs.com/papers

\title{
BRIDGING THE THEORY-PRACTICE GAP IN VALUE MANAGEMENT IN SRI LANKAN CONSTRUCTION INDUSTRY
}

\author{
M.M.M.P. Mahinkanda ${ }^{1}$, Y.G. Sandanayake ${ }^{2}$ and B.J. Ekanayake ${ }^{3}$
}

\begin{abstract}
Construction process is one of the most complex and dynamic procedures. Therefore, it is vital to use resources efficiently and effectively. Considering this requirement of any construction project, creating value for money is becoming important. It contributes to the economic, social and environmental aspects of a country. The concept of value is based on the relationship between satisfying needs, expectations and the resources required to achieve them. Value Management (VM) is recognised as a suitable approach to ensure value for money in construction projects. Although, VM concept is significantly used in developed countries, its applications do not seem to be well established in the construction industry in most of the developing countries including Sri Lanka. This is mainly due to lack of understanding of VM concept. Hence, this study aims to investigate how to bridge the theory-practice gap in VM in Sri Lankan construction industry, through seven case studies. Case study data collection was based on interviews, document review and observations and analysed using content analysis. The research findings revealed that these projects employed different kinds of VM methodologies derived from standard VM methodologies with the focus of various VM objectives. The study further identified number of reasons for theory-practice gap in VM such as lack of a formal guideline and less knowledge on VM, which dilute successful VM implementation. The experts further proposed train in-house VM facilitators, proper project planning, motivate investors, train Sri Lankan professionals by foreign experts and govern VM knowledge sharing as strategies to bridge the gap in order to deliver best value for client's money.
\end{abstract}

Keywords: Sri Lankan Construction Industry; Theory-Practice Gap; Value Management; Value Management Practice.

\section{INTRODUCTION}

Construction contributes to national economic growth necessities by means of costeffectiveness, timelines and would certainly contribute to cost saving for the country as a whole (Aibinu and Jagboro, 2002). Therefore, it is vital that resources applied as efficiently as possible and waste in any form should reduce to a minimum for a project due to its complexity (Coetzee, 2009). Considering this requirement as the fundamental purpose of any project, creating value for money is becoming vital (Gillier et al., 2015). Value for money is a crucial construct in project delivery (Barima, 2010). The concept of

\footnotetext{
${ }^{1}$ Department of Building Economics, University of Moratuwa, Sri Lanka, madhaveemahinkanda@gmail.com

${ }^{2}$ Department of Building Economics, University of Moratuwa, Sri Lanka, ysandanayake@uom.lk

${ }^{3}$ University of Technology Sydney, Australia, biyankaje@gmail.com
} 
value is based on the relationship between satisfying needs, expectations and the resources required to achieve them (Institute of Value Management Australia [IVMA], 2017). Rameezdeen and De Silva (2002) stated that enhancing the value of construction projects could create positive impact on the economy of a country. Managing value in construction projects leads to complete projects within stipulated time, anticipated cost and expected level of quality that meets requirements (Bowen et al., 2010).

As one of important tools for managing value of projects is VM, which is widely accepted concept in the construction industry (Ellis et al., 2005). Hayles et al. (2010) defined, VM as a proactive, problem solving or solution seeking process. Karim (2016) emphasised that this concept focuses not only about cost, but also emphasises about the relationship between function, value, quality and cost with functional analysis as its principal components. VM can be undertaken at any time, but best results can be obtained by applying early in a programme (Toy, 1995). The author further emphasised that the best time apply VM concept is at the stage where there is enough room for the planned action or design and sufficient cost information or procedure timetable to pursue realistic alternatives. Although, many researchers have addressed VM concept theoretically with published body of knowledge, there is a lack of $\mathrm{VM}$ implementation in construction industry (Jaapar et al., 2011).

The concept of VM is becoming more significant to Sri Lankan construction industry (Perera, et al., 2003). However, currently there is a need for VM in Sri Lanka to enhance efficiency and to deliver maximum value to benefit the stakeholders. Perera, et al., (2003) further disclosed that the practice of VM applications in the Sri Lankan context is not popular among the industry practitioners. Moreover, Ekanayake and Sandanayake (2017) highlighted that Sri Lankan construction industry need a proper value managing practice. As Karunasena and Gamage (2011) stated, although VM has introduced in Sri Lanka, there are challenges with its implementation and application. Authors further remarked major reason for less practice of VM in the country as less number of publications and manuals in the local construction industry, which are conversant with international VM methodology. There is a scarcity of resource persons in VM and it resultes the habit of non-formal usage of VM as well as limited use of formal methods (Perera et al., 2011). Although, researches have explored the VM in different perspectives in researches, there is a lack of evidences in research on how to bridge the theory and practice gap of VM concept in Sri Lankan construction industry. Finding out strategies to overcome the VM implementation barriers will pave the way for bridging the theory and practice gap.

\section{LITERATURE SYNTHESIS}

\subsection{THE CONCEPT OF VALUE AND ITS IMPORTANCE TO CONSTRUCTION INDUSTRY}

Value can be defined as the relationship between the satisfaction of various needs and the resources used for achieving it (Abidin and Pasquire, 2007). In simple form, value is "the ratio between the customer satisfaction (benefits) and the resources used (cost)" (Gillier et al., 2015, p. 948). In construction industry perspective, value maximisation of a construction project has been stated as one of the key goals in project portfolio management (Martinsuo and Killen, 2014). On other hand, managing projects for achieving value is very important in achieving goals of the project (Perera et al., 2003). 
In an effort to achieve value maximisation, many innovative control strategies are termed as best practices, value improving practices, and within that VM has shown successful results in achieving better performance (Cha and O'Connor, 2006). As a value enhancement technique, VM should not compromise the quality of project outcomes (Abidin and Pasquire, 2005). Value Analysis (VA) is early concept in VM journey and it was first introduced to the USA manufacturing industry by Lawrence D. Miles during World War II (Spaulding et al., 2005). Having originated in 1940's in the USA manufacturing industry, in 1954, the term Value Engineering (VE) was used by replacing VA due to its application in the USA military. Later, United Kingdom (UK) construction industry replaced the term VE to VM due to its core activity to fulfil the requirements for the examination of value instead of cost (Maznan et al., 2012).

There is no universally accepted definition for VM concept and it has many definitions from various authors' texts, guides and standards (Kelly et al., 2015). "VM is a service which maximises the functional value of a project by managing its evolution and development from concept to completion, through the comparison and audit of all decisions against a value system determined by the client or customer" (Kelly and Male, 1993). Jaapar et al. (2012) defined VM as an approach that improve the work relationship among the team and at the same time able to achieve better value for money for the projects.

In formal VM process, VM job plan is important (Shen et al., 2016). Authors further stated that VM job plan is a sequential approach to implement the basic and major elements of VM implementation. As identified by Kelly and Male (1993), the North American construction industry uses four formal approaches of VM job plan in different phases of a construction project namely, the Charette, the 40-hour workshop, The VE audit, and contractor's change proposal which are known as VM methods. The SAVE 40hour workshop, which was developed by SAVE International is one of the most popular VM job plans in the construction industry (Shen et al., 2016). Furthermore, 40-hour workshop consists of three main phases and six sub phases in workshop stage. This name was given due to the duration required for conducting the workshop (SAVE International, 1998a).

Shen and Liu (2004) have identified the various compositions of VM teams. Authors further identified, in most of the cases apart from the internal project team, invited VM experts and external resource persons related to construction become the VM team who come up with VM proposals.

VM concept has been proposed as an appropriate way to enhance the functionality of projects (Martinsuo and Killen, 2014). Further to Shen et al. (2016), VM is not a cost cutting technique, but is a concept, which focuses on best value at the lowest life cycle cost of a construction project.

According to Coetzee (2009), application of VM can result in savings of up to 5-15\% of the total costs involved in the project and therefore it is very effective to apply VM to large, expensive, complex, repetitive, restricted budgeted projects and projects with compressed design programmes. The application of VM in construction projects would highly depend on the value of a particular project and the level of the risks involved inside it (CIOB, 2017). 


\subsection{BARRIERS OF IMPLEMENTING VM IN CONSTRUCTION INDUSTRY}

The VM approach often faces challenges when applying in developing countries (Kim et al., 2016). Project stakeholders, especially the clients and consultants, depending on their less experience on VM studies their unwillingness to try something new can be identified as barriers for it (Oke and Aigbavboa, 2017). In Sri Lankan context it seems very clear that negative perception of the clients', less support from government/regulatory bodies and even if VM implemented the team not having formal VM experience dilutes VM applications (Perera, et al., 2003). Thus, to promote the application of VM, it was determined that identifying factors that impedes the adoption of VM would help. Then practitioners able to assess the barriers which prevents application, acceptance and implementation of VM strategies (Kim et al., 2016).

\subsection{THEORY AND PRACTICE OF VM}

As Kim et al., (2016) found out, especially in most of the developing countries, there is an issue of theory-practice gap of VM in construction industry. In terms of Malaysian construction industry context, there are minimal publications, guidelines, manuals and usage of VM knowledge became as major reasons for reluctance to follow VM approach for the construction projects in the country (Jaapur et al., 2009).

Bridging theory-practice gap of VM will provide new insights to enhance understanding of VM implementation in construction industry (Jaapar et al., 2011). In addition, authors stated that bridging the gap will lead to cost savings. Perera et al. (2003) stated that Sri Lankan construction industry can successfully implement VM by following and obtaining the knowledge from other developing countries on how they have successfully implemented VM.

\section{RESEARCH METHODOLOGY}

This research used qualitative research approach for achieving the research aim. Initially a comprehensive literature survey was carried out to identify the VM concept and its practice in both global and local construction industry. Based on the literature review, research question, which is "how to bridge the VM theory-practice gap in Sri Lankan construction industry?" was established.

Case studies were identified as the best method to achieve the research problem. Number of case studies were limited seven building construction projects, which have implemented VM concept due to lack of suitable projects. Interviews, observations and document review were identified as suitable data collection techniques. Collection of indepth information from the case studies was conducted until data saturation is reached. Content analysis is a qualitative data analysis technique, which is widely used for analysing documents and interviews (Hsieh and Shannon, 2005). Manual code based content analysis was used for the analysing the research findings.

Finally, interviews with two subject matter experts were carried out to validate the research findings in order to confirm the comprehensiveness of the findings.

\section{RESEARCH FINDINGS}

The seven case studies carried out through the research process, consisted of two apartment complexes, two hotel projects, one mixed development, laundry complex and 
a viewing gallery. In each case, four VM team members were selected for interviews among Clients, Architects, Engineers, Quantity Surveyors and Project Managers. VM reports of completed projects, VM workshop agendas and important e-mail copies were considered in document reviewing process. Further, VM applied projects were observed to get further knowledge on its applications. According to respondents' details, although nobody had formal VM qualification, most of them had previous VM experience.

\subsection{VM CONCEPT IN SRI LANKAN CONSTRUCTION INDUSTRY}

The research findings revealed that VM is still at its infant stage in Sri Lankan construction industry and there is no path to obtain formal VM qualification in Sri Lanka. The following section further elaborates the VM concept, awareness of it and the reasons for VM implementation in construction projects in Sri Lanka.

\subsubsection{Value Management}

The most frequently highlighted explanations for the term 'value management' in the context of construction industry given by the respondents are summarised below:

- Enhancing value of the output against its input

- Creating value through input resources to the project, which contribute to the whole life cycle of the project

- Completing a project at reduced cost without sacrificing any project component

- Getting the best output for client's money

- Managing cost without compromising value of the project

The above answers reveal that the respondents have marginal knowledge on VM concept, which affects the successful implementation of VM concept. Moreover, most of them do not have thorough idea on how it could improve sustainability, reduce life cycle cost and enhance functionality of elements.

\subsubsection{Awareness of VM Concept and Reasons for VM Implementation}

The respondents' ideas and knowledge on VM concept were collected in order to establish their view on VM, requirement of applying VM to the project and to identify the relation of them with available literature on theoretical aspect of VM.

All selected projects have practiced VM concept based on its own method and deviations from the standard VM practice can be observed. This was the main reason behind the selection of above mentioned research aim. Nevertheless, it is evident that the reasons for implementing VM for most of the selected building projects were, as a cost cutting technique and to optimise project cost in line with client's budget. The next common reason was to accelerate the project. However, it seems that although VM is a value improvement concept, it has gone to the industry nowadays as a cost cutting strategy rather than a value adding technique.

There should be a person or party to initiate VM application in a construction project. It depends on the nature of the project and the VM knowledge of each persons or professionals who involve in VM activities of the project. As per research findings, the situations where, VM implementing with client's opinion was very low. The only project VM initiated by client had a foreign client. It seems that in the Sri Lankan construction industry perspective, the traditional clients in Sri Lanka are not initiating ideas for VM implementation for the projects. However, in the contractors' perspective, Sri Lanka has 
the culture of implementing VM through contractors change proposals. In the case study, where VM implementation ideas initiated by the Engineer, the project has a foreign Engineer. In one of the cases, an Engineer performed the VM initiation as a result of being the consultant and the client of the same organisation.

\subsection{VM Application in SRi Lankan Building ProJects}

Implementation of VM activities during pre-contract and post contract stages affect the benefits of VM application. It was observed that among selected projects, only three projects have been implemented VM in both pre and post contract stages. The implementation of VM in pre-contract stage in a construction project, depends on the collaboration of client and the contractor with the engineer. To create the collaborative approach, contractor's contribution for the ideas is a requirement. The contractor's arrival at the pre-contract stage helps to pool the knowledge of all parties.

For the purpose of collecting information regarding VM composition of value team, respondents were asked about the criteria for selecting them. The most common answer given was according to the nature of the requirement of VM application, the team composition selected according to the element that VM is applied to. The most prominent feature identified from observed all the cases, the VM team for each case were the design team or project team or combination of both team members of the project. As revealed by case studies, when deciding the team composition, the stage of implementing VM is important as identified through cases. According to the observation of cases, it reveals that, VM team composition also depend on VM methodology followed.

Shen et al. (2016) stated that in a VM team, it is always beneficial to have a VM facilitator or a certified value specialist. However, when observing the case studies, there were no project found with a VM facilitator. The person who have the most overall knowledge in the project become in-house VM facilitator to the project in Sri Lankan context.

The intended purposes of implementing VM in each project are presented in Table 1.

Table 1: Objectives of VM implementation

\begin{tabular}{|c|c|c|c|}
\hline Case & $\begin{array}{l}\text { Planned } \\
\text { duration }\end{array}$ & $\begin{array}{c}\text { Actual } \\
\text { duration }\end{array}$ & Value Objectives \\
\hline Case A & 14 months & 14 months & $\begin{array}{l}\text { Controlling the budget overrun, Time saving, Cost } \\
\text { optimisation }\end{array}$ \\
\hline Case B & 3 years & 40 months & $\begin{array}{l}\text { To reduce the extra initial cost and optimise project cost, } \\
\text { Reducing energy consumption, Life cycle improvements, } \\
\text { Client satisfaction, Functional improvement, } \\
\text { Sustainability, Improving functions }\end{array}$ \\
\hline Case C & 4 years & 6 years & $\begin{array}{l}\text { Design optimisation as fit to the client's budget, } \\
\text { Sustainability }\end{array}$ \\
\hline Case D & 6 years & $\begin{array}{l}\text { Time } \\
\text { overrun due } \\
\text { to } \\
\text { arbitration }\end{array}$ & $\begin{array}{l}\text { Quality, Complying with hotel chain standards, } \\
\text { Unnecessary cost cutting, Saving huge labour cost, Not } \\
\text { affecting to the overall function }\end{array}$ \\
\hline Case E & 2.5 years & 2 years & $\begin{array}{l}\text { Structural stability, Acceleration, Fewer issues to the MEP } \\
\text { work and durability of material, Making convenience on } \\
\text { maintenance }\end{array}$ \\
\hline
\end{tabular}




\begin{tabular}{|c|c|c|c|}
\hline Case & $\begin{array}{l}\text { Planned } \\
\text { duration }\end{array}$ & $\begin{array}{c}\text { Actual } \\
\text { duration }\end{array}$ & Value Objectives \\
\hline Case F & 1 year & 9 months & $\begin{array}{l}\text { To obtain constructability, Sustainability, Cost reduction, } \\
\text { Time acceleration, Quality improvement }\end{array}$ \\
\hline Case G & 2 years & $\begin{array}{l}\text { Not } \\
\text { finalised }\end{array}$ & $\begin{array}{l}\text { To reduce excessive cost allocated for pile deck ponding, } \\
\text { To accelerate the project to complete within allocated time } \\
\text { period, To save unnecessary additional cost }\end{array}$ \\
\hline
\end{tabular}

It can be identified that, objectives of VM application in each project were different. But in most of the cases, the main purpose of implementing VM was for cost cutting.

\subsection{THEORY-PRACTICE GAP OF VM}

One of the objectives of this study is to identify the teary-practice gap of VM. The identified practices of VM from case studies compared to the theoretical aspects are summarised in Table 2.

Table 2: VM theory vs practice

\begin{tabular}{|c|c|c|}
\hline & $\begin{array}{c}\text { Systematic VM Applications } \\
\text { (Theory) }\end{array}$ & $\begin{array}{c}\text { VM Application in Sri Lanka } \\
\text { (Practice) }\end{array}$ \\
\hline VM Team & $\begin{array}{l}\text { Comprise of VM experts, Design/ } \\
\text { Project team and the Client }\end{array}$ & Comprise of design / project team \\
\hline VM Facilitator & $\begin{array}{l}\text { Qualified VM facilitator (Certified } \\
\text { Value Specialist) is available }\end{array}$ & $\begin{array}{l}\text { Person who has overall idea of the } \\
\text { project will be the VM facilitator }\end{array}$ \\
\hline VM Approach & $\begin{array}{l}\text { Collaborative approach of Client, } \\
\text { Consultant, Contractor and VM } \\
\text { experts }\end{array}$ & $\begin{array}{l}\mathrm{VM} \text { approach is based on client or } \\
\text { project team requirements }\end{array}$ \\
\hline VM Workshop & $\begin{array}{l}\text { Conduct systematic formal VM } \\
\text { workshops }\end{array}$ & $\begin{array}{l}\text { Conduct VM discussion meetings } \\
\text { in ad-hoc manner }\end{array}$ \\
\hline VM Focus & $\begin{array}{l}\text { Cost optimisation, time acceleration, } \\
\text { quality improvement, functional } \\
\text { improvement and performance } \\
\text { improvement }\end{array}$ & $\begin{array}{l}\text { Cost reduction and time } \\
\text { acceleration }\end{array}$ \\
\hline $\begin{array}{l}\text { VM } \\
\text { Implementation }\end{array}$ & $\begin{array}{l}\text { Implement at the inception or design } \\
\text { stage to gain best output }\end{array}$ & $\begin{array}{l}\text { Implement to overcome issues } \\
\text { such as cost or time overrun, } \\
\text { specially during construction stage }\end{array}$ \\
\hline Documentation & $\begin{array}{l}\text { Whole process and expected outcomes } \\
\text { are formally documented. }\end{array}$ & Very less documentation \\
\hline $\begin{array}{l}\text { Decision } \\
\text { Making }\end{array}$ & $\begin{array}{l}\mathrm{VM} \text { team and } \mathrm{VM} \text { specialist } \\
\text { responsible for decisions }\end{array}$ & $\begin{array}{l}\text { Proposer has the responsibility and } \\
\text { risk }\end{array}$ \\
\hline $\begin{array}{l}\text { Project } \\
\text { Programme }\end{array}$ & $\begin{array}{l}\text { Allocate time for VM workshop in } \\
\text { project programme }\end{array}$ & $\begin{array}{l}\text { Specific time is not allocated for } \\
\text { VM workshop }\end{array}$ \\
\hline $\begin{array}{l}\text { Monitoring } \\
\text { Results }\end{array}$ & $\begin{array}{l}\text { VM team monitor the interim progress } \\
\text { and compare the results with } \\
\text { established expected outcomes }\end{array}$ & $\begin{array}{l}\text { No one monitors the interim } \\
\text { progress compared to expected } \\
\text { outcomes. }\end{array}$ \\
\hline
\end{tabular}

Aforementioned findings presented in Table 2 confirms that Sri Lankan construction industry practitioners do not have thorough knowledge on VM concept and its correct 
implementation. Hence, it is evident that there is a theory and practice gap in VM implementation in Sri Lanka. Therefore, there is a need to investigate the strategies to bridge the VM theory-practice gap.

\subsection{STRATEGIES TO BRIDGE VM THEORY-PRACTICE GAP}

For investigating theory and practice gap of VM concept in Sri Lankan construction industry, it is very important to identify the barriers. Strategies to overcome from the barriers identified in this study are mapped in Figure 1.

\begin{tabular}{|c|c|}
\hline $\begin{array}{l}\text { Barriers for Implementing VM } \\
\text { Concept }\end{array}$ & $\begin{array}{l}\text { Strategies for Successfully } \\
\text { Implementing VM Concept }\end{array}$ \\
\hline $\begin{array}{l}\text { Prevailing condition of contract and } \\
\text { procurement methods not support to VM } \\
\text { application }\end{array}$ & $\begin{array}{l}\text { Learn theories and practical aspects of } \\
\text { VM and introduce value certificate } \\
\text { courses and VM higher studies }\end{array}$ \\
\hline $\begin{array}{l}\text { Difficulty of selecting suitable VM } \\
\text { methodology for different construction } \\
\text { projects }\end{array}$ & $\begin{array}{l}\text { Select suitable procurement method } \\
\text { which suit to involve contractors' ideas } \\
\text { in pre-tender stage }\end{array}$ \\
\hline $\begin{array}{l}\text { VM findings complicated, long procedure } \\
\text { or abstracted to be in practical view }\end{array}$ & $\begin{array}{l}\text { Advise the clients on importance of } \\
\text { implementing VM }\end{array}$ \\
\hline $\begin{array}{l}\text { Lack of government legislation/ policy, } \\
\text { guidance block and less motivation to } \\
\text { implement VM }\end{array}$ & $\begin{array}{l}\text { Adjust organisation structure to suit } \\
\text { VM implementation }\end{array}$ \\
\hline $\begin{array}{l}\text { VM workshops take time and additional } \\
\text { cost }\end{array}$ & $\begin{array}{l}\text { Promote central coordination of } \\
\text { project to practice VM and proper } \\
\text { project planning }\end{array}$ \\
\hline $\begin{array}{l}\text { Research based VM knowledge } \\
\text { practicability, transferring to industry is } \\
\text { poor }\end{array}$ & $\begin{array}{l}\text { Collaborate with contracting and } \\
\text { consulting organisations when } \\
\text { implementing VM }\end{array}$ \\
\hline Lack of qualified VM facilitators & $\begin{array}{l}\text { Submit alternative bid with VM } \\
\text { proposal }\end{array}$ \\
\hline $\begin{array}{l}\text { The awareness of VM and its application } \\
\text { in the construction industry is low and } \\
\text { wrong VM practices }\end{array}$ & $\begin{array}{l}\text { Introduce contractual provisions for } \\
\text { consultants to get monetary reward for } \\
\text { VM implementation }\end{array}$ \\
\hline $\begin{array}{l}\text { Less commitment from top management } \\
\text { to implement VM }\end{array}$ & $\begin{array}{l}\text { Govern VM knowledge VM research } \\
\text { knowledge sharing and controlling }\end{array}$ \\
\hline $\begin{array}{l}\text { Lack of communication with overseas } \\
\text { VM practitioners Lack of communication } \\
\text { with overseas VM practitioners }\end{array}$ & $\begin{array}{l}\text { Motivate investors and professionals } \\
\text { by conducting mock up workshops and } \\
\text { seminars on VM }\end{array}$ \\
\hline $\begin{array}{l}\text { Difficulty of gathering all professionals } \\
\text { for VM team in the same time }\end{array}$ & $\begin{array}{l}\text { Post evaluation of projects and } \\
\text { document lessons learned }\end{array}$ \\
\hline $\begin{array}{l}\text { Tight work schedule allocated for } \\
\text { consultants, no special monetary benefit } \\
\text { for consultant and ego issues of } \\
\text { professionals }\end{array}$ & $\begin{array}{l}\text { Assist government to develop VM } \\
\text { implementation guideline and support } \\
\text { by funding or giving tax benefits for } \\
\text { VM implementing projects }\end{array}$ \\
\hline $\begin{array}{l}\text { Clients' perception issues and conflicts } \\
\text { between value team and design/project } \\
\text { team }\end{array}$ & $\begin{array}{l}\text { Improve attitude of the professionals } \\
\text { and forward VM practitioners to } \\
\text { implement VM }\end{array}$ \\
\hline $\begin{array}{l}\text { Sustainability factors rejected by } \\
\text { traditional clients }\end{array}$ & $\begin{array}{l}\text { Observe international aspects, obtain } \\
\text { foreign experts' knowledge on VM } \\
\text { and decide what suits to Sri Lanka }\end{array}$ \\
\hline
\end{tabular}

Figure 1: Strategies for bridging VM theory-practice gap

Findings indicated in Figure 1 reveals that there are number of barriers, which demotivate proper VM implementation and lead to theory-practice gap in VM application in Sri Lankan construction industry. The study further identified tight work schedules and 
ego of professionals as key reasons that hamper the successful implementation of VM in construction projects. Hence, the implementation of VM in Sri Lankan construction industry is far from theoretical and standard VM practices.

The key strategies proposed to bridge the VM theory-practice gap in Figure 1 includes: (a) develop VM education process, (b) selection of suitable procurement method, (c) proper project planning, (d) motivate investors and professionals, (e) train VM facilitators and (f) govern VM knowledge sharing. Hence, the study makes recommendations for bridging VM theory-practice gap in order to deliver value for client's money.

\section{DISCUSSION AND CONCLUSIONS}

VM has been globally implemented to gain lot of savings and benefits. However, in Sri Lankan construction industry, it is evident that the application of VM is lacking. Bridging the theory-practice gap of VM derived as a requirement based on these circumstances which mainly contributes to economy of the country. VM is a value enhancement strategy. The case study findings also revealed that the projects have used VM to achieve different VM objectives, whilst delivering value for money. However, VM concept has not deeply rooted to the Sri Lankan construction industry and the VM teams mainly use it to reduce costs in construction projects.

The respondents highlighted that, if systematic VM process carried out, the outcome of VM implementation would be better than current situation. The other most prominent finding was although most popular VM job plan in the construction industry is SAVE 40hour workshop, Sri Lankan construction industry more familiar with "contractors change proposal" than other methodologies. The reason for that is provided provision for it from the contractual arrangements such as FIDIC and Standard Bidding Document (SBD). However, findings revealed that there are number of theory-practice gaps in VM application in Sri Lankan construction industry, which de-motivates proper VM implementation. Due to these gaps, the implementation of VM in Sri Lankan construction sector is far from theoretical and standard VM practices.

The strategies proposed to bridge the VM theory-practice gap include train in-house VM facilitators, proper project planning, motivate investors, train Sri Lankan professionals by foreign experts and govern VM knowledge sharing. Hence, this study recommends that VM should be properly and systematically initiated in Sri Lankan construction industry by bridging existing gaps of theory-practice through the strategies in order to deliver value for client's money.

\section{REFERENCES}

Abidin, N. Z. and Pasquire, C. L., 2005. Delivering sustainability through value management: Concept and performance overview. Engineering, Construction and Architectural Management, 12(2), pp.168-180.

Abidin, N. Z. and Pasquire, C. L., 2007. Revolutionize value management: A mode towards sustainability. International Journal of Project Management, pp.275-282.

Aibinu, A. and Jagboro, G., 2002. The effects of construction delays on project delivery in Nigerian construction industry. International Journal of Project Management, 20(8), pp.593-599.

Bowen, P., Cattell, K., Edwards, P. and Jay, I., 2010. Value Management Practice by South African Quantity Surveyors. Facilities, 28(1/2), pp.46-63.

Cha, H. and O'Connor, J., 2006. Characteristics for Leveraging Value Management Processes on Capital Facility Projects. Journal of Management in Engineering, 22(3), pp.135-147. 
Chartered Institute of Building Construction [CIOB], 2017. Value management in building design and construction. [Online] Available at: https://www.designingbuildings.co.uk/wiki/Value_management_in_building_design_and_constructio n [Accessed 17 December 2018].

Coetzee, C. E., 2009. Value Management in the Construction Industry: What Does It Entail and is it A Worth Practice. University of Pretori.

Ekanayake, A. C. and Sandanayake, Y. G., 2017. LiVE approach: lean integrated value engineering for construction industry. Built Environment Project and Asset Management, 7(5), pp.518-533.

Ellis, R. C. T., Wood, G. D. and Keel, D. A., 2005. Value management practices of leading UK cost consultants. Construction Management and Economics, 23(5), pp.483-493.

Gillier, T., Hooge, S. and Piat, G., 2015. Framing value management for creative projects: An expansive perspective. International Journal of Project Management, 33(4), pp.947-960.

Hayles, C., Graham, M. and Fong, P. S. W., 2010. Value management for sustainable decision making. Municipal Engineer, March, pp.43-60.

Hsieh, H. F. and Shannon, S. E., 2005. Three Approaches to Qualitative Content Analysis. Qualitative Health Research Journal, 15(9), pp.1277-1288.

Institute of Value Management Australia [IVMA], 2017. Institute of Value Management Australia. [Online] Available at: http://ivma.org.au/value-management/application-of-value-management [Accessed 3 January 2018].

Jaapar, A., Maznana, N. and Zawawia, M., 2012. Implementation of Value Management in Public Projects. pp.77-86.

Jaapar, A., Zawawi, M., Bari, N. and Ahmad, N., 2011. Value Management in the Malaysian Construction Industry: Addressing a Theory and Practice Gap. Famagusta, North Cyprus, pp.757-763.

Jaapur, A., Endut, I. R., Bari, N. and Takim, R., 2009. The Impact of Value Management Implementation in Malaysia. Journal of Sustainable Development, 2(2), pp.210-219.

Karim, S. B. A., 2016. The Application of Value Management on Private Projects. QS Link, pp.33-36.

Karunasena, G. and Gamage, O., 2011. Value Achievement in Construction Industry. Colombo, Department of Building Economics, Universityof Moratuwa, pp.152-161.

Kelly, J. and Male, S., 1993. Value Management in Design and Construction: The Economic Management of Projects. London: E and FN Spon, an imprint of Chapman and Hall.

Kelly, J., Male, S. and Graham, D., 2015. Value Management of Construction Projects. $2^{\text {nd }}$ ed. West Sussex: John Wiley and Sons.

Kim, S., Lee, Y., Nguyen, V. and Luu, V., 2016. Barriers to Applying Value Management in the Vietnamese Construction Industry. Journal of Construction in Developing Countries, 21(2), pp.55-80.

Martinsuo, M. and Killen, C. P., 2014. Value Management in Project Portfolios: Identifying and Assessing Strategic Value. Project Management Journal, 45(5), pp.56-70.

Mat, M. M. C., 2014. Value management - The way forward, Institute of Value Management Malaysia.

Maznan, N. A., Bari, N. A. A. and Zawawi, M., 2012. Value Management: Private Sector's Perception. Bangkok, pp.383-391.

Oke, A. and Aigbavboa, C., 2017. Barriers of Sustainable Value Management. In: Sustainable value management for construction projects. pp.169-177.

Perera, S., Hayles, C. S. and Kerlin, S., 2011. An analysis of value management in practice: the case of Northern Ireland's construction industry. Journal of Financial Management of Property and Construction, 16(2), pp.94-110.

Perera, S., Karunasena, G. and Selvadurai, K., 2003. Application of Value Management in Construction. Built Environment Sri Lanka, 4(1), pp.3-12.

Rameezdeen, R. and De Silva, S., 2002. Trends in construction procurement systems in Sri Lanka. Built Environment Sri Lanka, 2(2), pp.2-9.

SAVE Iinternational, 1998a. Function: definition and analysis. [Online] Available at: http://www.valueeng.org/pdf_docs/monographs/funcmono.pdf [Accessed 25 August 2018].

Shen, Q. and Liu, G., 2004. Applications of value management in the construction industry in China. Engineering, Construction and Architectural Management, 11(1), pp.9-19. 
Shen, Q., Yu, A. and Chung, K., 2016. VM Applications. In: Value Management in Construction and Real Estate. New York: Routledge, pp.66-67.

Spaulding, W. M., Bridge, A. and Skitmore, M., 2005. The use of function analysis as the basis of value management in the Australian construction industry. Construction Management and Economics, 23(7), pp.723-731.

Toy, T., 1995. Value of VM Facilitation, The Hong Kong Institute of Value Management.

Yin, R. K., 2014. Case study research: Design and methods. $5^{\text {th }}$ ed. CA: Sage Publications. 